Arab World English Journal (AWEJ) $2^{\text {nd }}$ Special Issue on Covid 19 Challenges January 2022 DOI: https://dx.doi.org/10.24093/awej/covid2.29

Pp.437-452

\title{
Investigating the Intrinsic Motivation among Second Language Learners in Using Digital Learning Platforms during the Covid-19 Pandemic
}

\author{
Zuraina Ali \\ Centre for Modern Languages, Universiti Malaysia Pahang \\ Pahang, Malaysia \\ Email: zuraina@ump.edu.my
}

Received:11/27/2021 Accepted:1/4/2022 Published:1/24/2022

\begin{abstract}
The study aims to investigate the intrinsic motivation among L2 in their uses of digital learning platforms during the Covid-19 pandemic. In particular, the central questions in the study are to identify the profiles of intrinsic motivation among L2 learners using digital learning platforms, determine gender differences using digital learning platforms, investigate the difference in motivation according to students' performances, and describe the perceived enjoyment of using digital learning platforms. The study that used a questionnaire to collect data among 72 engineering students found positive intrinsic motivation utilizing the medium to learn English. However, there was insufficient evidence to show a difference between gender using the digital learning platforms with intrinsic motivation. There was also insufficient evidence to prove that grades are associated with students' intrinsic motivation when the teacher assigned synchronous or asynchronous classroom tasks. Yet, the present study found that publishing works in Canva and writing posts on LinkedIn were among the students' most preferred digital learning platforms activities. The study is significant to teachers since it assists them in managing classes and discovering the uses of digital learning platforms for a conducive learning atmosphere during the pandemic. It is recommended that teachers need to be creative in using digital learning platforms to promote collaborative learning among learners.
\end{abstract}

Keywords: Covid-19 pandemic, digital learning platforms, intrinsic motivation, L2 learners Cite as: Ali, Z. (2022). Investigating the Intrinsic Motivation among Second Language Learners in Using Digital Learning Platforms during the Covid-19 Pandemic Arab World English Journal (AWEJ) $2^{\text {nd }}$ Special Issue on Covid 19 Challenges (2) 437-452.

DOI: https://dx.doi.org/10.24093/awej/covid2.29 
Arab World English Journal (AWEJ) 2nd Special Issue on Covid 19 Challenges January 2022

Investigating the Intrinsic Motivation among Second Language Learners

Ali

\section{Introduction}

The present issue concerning the pandemic of Covid 19 is the nation's most significant concern that affects all segments of the population. The infectious and deadly coronavirus that began in China has spread to more than 44 countries worldwide is alarming (Coote \& Dunleavy, 2020). In effect, many academic institutions - schools and tertiary level institutions, have to be closed and now adapting to digital learning platforms to ensure students can still learn, albeit with the increasing cases of people affected with the virus. Also, due to the pandemic, education has changed tremendously. The rise of e-learning requires teachers to use digital learning platforms in their teaching and learning. In Malaysia, the adoption of online learning is still in progress, and it cannot be determined that the sudden shift of digital learning platforms is here to stay after the pandemic is over. To ensure the smooth running of classes, Li and Lalani (2020) state that language apps, virtual tutoring, video conferencing tools, or online learning software are examples of digital learning platforms widely used since the spread of Covid 19.

Recently, researchers (Fansury et al., 2020; Kaharuddin, 2020; Subakthiasih \& Putri, 2020) have increased interest in investigating digital learning platforms for English learning during the pandemic. Integrating technology into the language class affected the motivation among English as a Foreign (EFL) learners in Kaharuddin's (2020) study directly and directly. The motivation among his samples, i.e., high school students in learning English, could be strengthened if they showed positive attitudes towards using the digital learning platforms. In addition, more than half of the high school students strongly agreed that using digital content during the Covid 19 pandemic motivated their learning of English (Fansury et al., 2020). Teachers interviewed in the study also believed that digital content could make their EFL learners learn the language better. In return, they believed that students who learned English using the resource would learn abroad.

Meanwhile, Subakthiasih and Putri's (2020) students demonstrated higher intrinsic motivation than extrinsic motivation learning English during the pandemic. They reported possessing self-driven nature to learn English as they wanted to improve their English skills. Moreover, they used their free time to learn the language at home because they enjoyed the learning process. Finally, their satisfaction in understanding other peoples' culture, values, and thoughts made them learn English according to their free will.

Nevertheless, the most significant challenge of using digital learning platforms during the pandemic is identifying their types for successful online learning. Previous studies investigated the learners' direct and indirect motivation using digital learning platforms (Fansury et al., 2020), while Kaharuddin (2020) did not mention the platforms he employed for the digital content. Also, Subakthiasih and Putri's (2020) study did not offer insights into intrinsic motivation as only close-ended questionnaire items were used to collect data in their research. Therefore, the nature of using digital learning materials during the pandemic remains unclear. This paper, thus, attempts to identify the profiles of learners about their intrinsic motivation using digital learning platforms to learn English. Also, it gauges gender differences in the use of the platform, identifies the differences in motivation according to the students' grades in English, and finally describes their perceived enjoyment of using the platforms for learning the language. The research questions formulated in the current study are: 
1. What are the students' intrinsic motivation profiles using digital learning platforms in learning English?

2. Are males more motivated than females in using digital learning platforms in learning English?

3. Is there a difference in motivation scores for outstanding, above average, average and below-average students?

4. What is the perceived enjoyment of using digital learning platforms among the students?

\section{Literature Review}

\section{Defining Digital Learning Platforms}

Harman (2021, para. 1) defines a digital learning platform as a Learning Management System (LMS) or Learning Content Management System (LCMS) employed during learning. The term can also describe a virtual classroom tool or Virtual Learning Environment (VLE). All digital learning platforms support various types of learning, be it online learning, classroom learning, or blended learning. Due to the coronavirus, online learning required specialized technology solutions to support the learners and timely digital learning platforms. Brown (2021, para. 1-2) used the term digital education platform to mean purpose-built remote learning used among learners. It is a set of tools and technologies that allows learners to learn online in a virtual classroom. Its use was relevant due to the close of schools and tertiary level education around the globe due to the coronavirus pandemic where teachers need to find ways to continue teaching at home (Brown, 2021, para. 1-2). In the context of the study, the digital learning platforms are the online tools for drawing, publishing, creating, storing, and establishing a network for the learning of English. Specifically, the study investigates the use of publishing tools, namely Canva and Google Drawing, the LinkedIn social network for students' professional networking and career development, and Google Docs applications that students can use to create, edit and store their works online. The study employed the platforms for various activities for instance drawing mind maps using Canva and Google Drawing, writing postings on LinkedIn according to topics identified by the teacher, and using Google Docs for writing, editing, and storing their respective works.

\section{Intrinsic Motivation}

Ryan and Deci (2000, p.56) define motivation as people's actions resulting from excitement or enjoyment. Those who demonstrate intrinsic motivation in doing something can achieve high quality of learning and boost their creativity. When they perform a task out of their willingness, they demonstrate a feeling of satisfaction, improve competency, and become selfdetermined to complete a given task. Ryan and Deci (2000), the founder of the Selfdetermination theory, further argue that intrinsic motivation started as early as when someone was born in this world. The characteristics of a child being active, inquisitive, curious, playful, ready to learn, and explore, do not require extraneous incentives to engage in the activities the child is enjoying. The willingness to know of a child, in this instance, is a critical element in his/her cognitive development because intrinsic motivation exists within individuals (Ryan \& Deci, 2000). Yet, the scholars argue that it can also occur in adults when they perform activities. For example, people can be intrinsically motivated to do an activity but not other activities. Also, not everyone can make the intrinsic motivation grows in him/herself. In short, intrinsic motivation is the feeling when a particular activity is enjoyable to the person, and therefore, he/she becomes engaged doing it. In other words, the reward or satisfaction comes from the 
activity itself and not from other factors. Figure 1 shows the Self-determination framework used in the study concerning intrinsic motivation by Ryan and Deci (2000). It shows that in Selfdetermination Theory, people with intrinsic motivation are self-determined. They conform to the intrinsic regulations in completing a task. Hence, when they engage in a task, they do it with interest, enjoyment and satisfaction. Their perceived locus of causality is internal, and therefore, they complete a task due to their own choice, acknowledgement of feelings and opportunities for self-direction. In other words, they have the autonomy to decide on how to go about with the task and complete it.

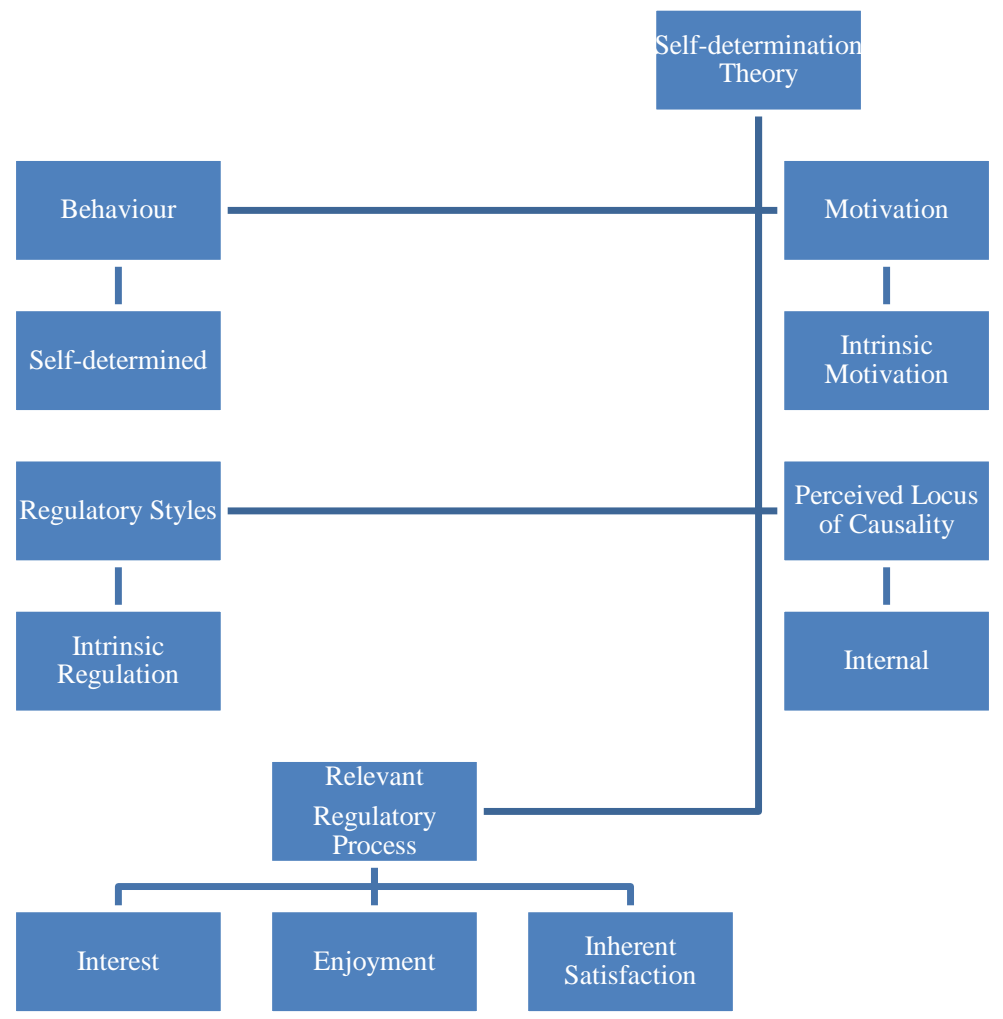

Figure 1. Self-determination theory focusing on Intrinsic Motivation

(Source: Adapted from Ryan and Deci, 2000)

\section{Conceptual Framework of the Study}

A conceptual framework is vital in every scientific inquiry. Towne and Shavelson (2002) state that it links implicitly or explicitly to the systematic way of conducting research. Its use produces answers to the formulated research questions as well. Researchers construct a conceptual framework to show the relationship among variables and how they relate to the study. It is also used to show that the researchers understand the connections of the particular variables employed in their research (Regoniel, 2015). Figure 2 shows the conceptual framework administered in the current study. In investigating digital learning platforms to learn English, intrinsic motivation is the tested variable (dependent variable), while age and grades in English are the variables the researcher manipulates (independent variables) to examine their direct effect on the dependent variable. 


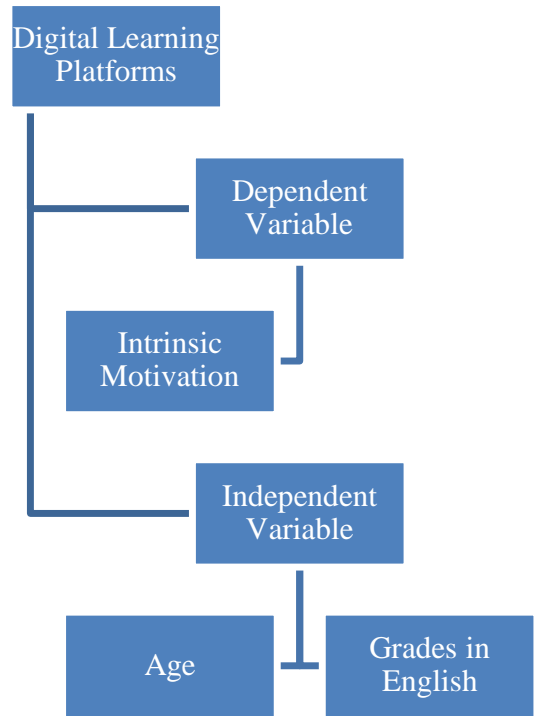

Figure 2. Conceptual Framework of the current study

\section{Use of Digital Learning Platforms to Learn English During the Pandemic}

The force of nature when people, particularly educators and learners, across the globe are affected by the coronavirus leads to the use of digital learning platforms in all academic institutions - regardless in schools or tertiary levels education. Nugroho and Atmojo (2020) investigated Indonesian EFL learners' perceptions of using digital learning platforms to learn the language. Their study found that students positively perceived the platforms' implementation during the pandemic. It encouraged their learning efficacy and enhanced their language productivity. Also, learning English through digital technologies motivated them to learn beyond the classroom walls. Learners learning English and German found that digital learning platforms enabled them to gain the linguistic and cultural experience of a native speaker in a virtual space (Masterson, 2020). Teachers also found that their students were more engaged as learning was related directly to their world. Yet, the teachers assisted the learners on various occasions since their students lacked the vocabulary to communicate with their partners, who are native speakers. As a result, the support received from the teachers and the native speakers provided the language learners with richer learning experiences.

The failure to have a good Internet connection hinders the implementation of online learning regardless of the digital learning platform used in language class. Nartiningrum and Nugroho (2020) studied the EFL learners' challenges attending online courses using Zoom and Google Meet during the pandemic. The bad signals and often electricity blackouts were the reason they did not favor the digital learning platforms when online classes were conducted. They found it challenging to learn without meeting face-to-face with their instructors, and as a result, they could not understand the learning materials. Also, it was a challenge for students as they were unable to get feedback from their instructors concerning the answers they provided in the assigned tasks. Likewise, an unstable internet connection was the challenge faced by the students in Haratikka's (2020) study. Her study examined five online learning platforms: Google Classroom, WhatsApp, Zoom Meeting, Youtube, and Google Form. Due to the connection that was not stable for many students, the study found that the best platforms for online lessons were 
to use Google Classroom and WhatsApp. Using these tools, they could ask questions using WhatsApp and access Google Classroom for the assigned tasks prepared by the instructors.

\section{Method}

\section{Research Design}

The study employs a mixed-method research design, specifically the explanatory sequential research design, to collect the data for the current study. When carrying out the method, quantitative research was conducted first since it served as the foundation to build more detailed qualitative research (Creswell, 2014). It is explanatory since the initial quantitative data are further explained in the qualitative data. It is also sequential because quantitative data has to be collected or analyzed before collecting and analyzing the qualitative data.

\section{Participants}

Table 1 shows the demographic details of the participants in the study. Seventy-two students participated in the survey, with 45 males and 27 females. In terms of gender, most of them are 23 to 25 years old. For grades, most of them scored above average in the English subject they took in the previous semester. Finally, they are students taking various engineering courses studying in a public technical university on the East Coast of Malaysia.

\section{Table 1. Participants' demographic information}

\begin{tabular}{|c|c|c|c|}
\hline Variables & Frequency & Percent & Cumulative Percent \\
\hline \multicolumn{4}{|l|}{ Gender } \\
\hline Male & 45 & 51.7 & 62.5 \\
\hline Female & 27 & 31.03 & 37.5 \\
\hline Total & 72 & 82.8 & 100.0 \\
\hline \multicolumn{4}{|l|}{ Age } \\
\hline $20-22$ & 14 & 16.1 & 19.4 \\
\hline $23-25$ & 56 & 64.4 & 77.8 \\
\hline $26-28$ & 2 & 2.3 & 2.8 \\
\hline Total & 72 & & \\
\hline \multicolumn{4}{|l|}{ Previous semester's English Grades } \\
\hline Outstanding achievement & 16 & 18.4 & 22.2 \\
\hline Above average & 45 & 51.7 & 62.5 \\
\hline Average achievement & 11 & 12.6 & 15.3 \\
\hline Total & 72 & & \\
\hline \multicolumn{4}{|l|}{ Faculty } \\
\hline Faculty of Manufacturing and & 23 & 26.4 & 31.9 \\
\hline \multicolumn{4}{|l|}{ Mechatronic Engineering Technology } \\
\hline Faculty of Computing & 31 & 35.6 & 43.1 \\
\hline $\begin{array}{l}\text { Faculty of Mechanical and Automotive } \\
\text { Engineering Technology }\end{array}$ & 11 & 12.6 & 15.3 \\
\hline \multirow{2}{*}{$\begin{array}{l}\text { Faculty of Electrical and Electronics } \\
\text { Engineering Technology }\end{array}$} & 7 & 8.0 & 9.7 \\
\hline & 72 & 82.8 & 100.0 \\
\hline
\end{tabular}

\section{Instruments}

A questionnaire was employed to obtain the data for the current study. It consists of eight items about students' intrinsic motivation for using digital learning platforms to learn English. It consists of eight close-ended and two close-ended items. The items were adapted from Brown's (2000) list of questions to promote intrinsic motivation when designing the classroom 
techniques. The researcher's colleague validated the instrument in terms of its content-criterion validity. On the face-validity level, she confirmed that the items are relative to the dependent variables tested in the study. Also, she confirmed that the wordings used in the questionnaire were appropriate for the student's English level. Regarding reliability, the intrinsic motivation scale consists of 8 items produced $(\alpha=.91)$.

\section{Procedures}

The data collection procedures began by asking participants for their willingness to complete an online form, i.e., via Google Form. Students who are taking Semester I 2021/2022 class volunteered to participate in the study were provided three days to answer all the items in the questionnaire. After three days, the researcher used the 'Not accepting response' button in the Google Form begin analyzing the data. At this stage, all the data saved using an Excel sheet when using Google Form was transferred to Statistical Package for the Social Sciences (SPSS) Version 21. In terms of the procedures for analyzing the data, descriptive statistics were used to answer Research Question 1.

In contrast, inferential statistics were employed to answer Research Question 2 and Research Question 3. Thematic analysis was conducted to analyze the qualitative data, i.e., Research Question 4. In reporting the data for the qualitative inquiry, without breaching anonymity, the students were identified as S1 to indicate Student 1, S2 means Student 2, and so forth. Also, verbatim transcription was employed in reporting the students' responses, and therefore, grammatical errors made by them in typing their responses were not corrected.

\section{Results}

\section{Normality test}

A normality test was conducted to ensure the distribution of scores on the dependent variable; in this case, intrinsic motivation is 'normal.' It can be assessed to some extent by running the Kolmogorov-Smirnov statistics (Pallant, 2005). If the score of Asymp. Sig (2-tailed) of Kolmogorov-Smirnov is higher than the level of significance 0.05 (>0.05); the variable is normally-distributed and vice versa. The normality test in Table 2 shows Total Intrinsic Motivation is normally distributed since the score of Asymp. Sig (2-tailed) is .063.

Table 2. Test of Normality

Total Intrinsic Motivation

\begin{tabular}{ccc}
\multicolumn{3}{c}{ Kolmogorov-Smirnov $^{\text {a }}$} \\
\hline Statistic & Df & Sig. \\
\hline .102 & 72 & .063
\end{tabular}

\section{a. Lilliefors Significance Correction}

\section{Profiles of students' intrinsic motivation using digital learning platforms in learning English}

Table 3 relates to students' opinions on the formulated statements in the questionnaire's items about their intrinsic motivation to use digital learning platforms learning English during the pandemic. The table shows that the moderate mean scores concern Item $3(\mathrm{M}=3.96$, SD $=.89$ ). Students felt that they fairly obtained sufficient information or feedback from the teacher after administering activities. Item 4 demonstrates a high mean score $(\mathrm{M}=4.17, \mathrm{SD}=.84)$. It showed that students could use effective strategies in learning since they could recall and make 
notes to the assigned tasks given by the teacher. Item 1 and 5 both have the same mean - for Item $1(\mathrm{M}=4.08, \mathrm{SD}=.76)$ and Item $5(\mathrm{M}=4.08, \mathrm{SD}=.83)$, respectively. Students strongly agreed that they could be autonomous and independent in completing the assigned tasks. They also highly approved that the activities exposed themselves to various possible ways of completing the assigned tasks. While Item 6 showed a high mean score $(\mathrm{M}=4.18, \mathrm{SD}=.69)$ concerning their opinions on how to complete the assigned tasks. As demonstrated in Item $2(\mathrm{M}=4.25, \mathrm{SD}=.75)$, it was interesting that the students could negotiate or communicate with their coursemates when the teacher assigned interactive works. Another high mean score was obtained for Item 8 $(\mathrm{M}=4.34$, $\mathrm{SD}=.87)$. It showed that students strongly agreed that they knew the teachers' objectives to assign a particular task. Finally, the highest mean score is in Item $7(\mathrm{M}=4.50$, SD $=.75$ ). Almost majority of the students believed that the activities assigned to them were relevant and could benefit them in the future.

Table 3. Students' intrinsic motivation profile

\begin{tabular}{|c|c|c|}
\hline & Mean & Std. Deviation \\
\hline $\begin{array}{l}\text { 1. I feel that I have the autonomy and be independent as I complete the } \\
\text { assigned activities }\end{array}$ & 4.08 & .76 \\
\hline $\begin{array}{l}\text { 2. I feel that the activities given by the lecturer are interactive as I can } \\
\text { negotiate with my coursemates }\end{array}$ & 4.25 & .75 \\
\hline 3. I receive sufficient feedback on the activities I have completed & 3.96 & .89 \\
\hline $\begin{array}{l}\text { 4. I can develop or use effective strategies of learning (e.g., I can recall what } \\
\text { I did in responding to the activities, I can make notes on the important } \\
\text { things that the lecturer is delivering) }\end{array}$ & 4.17 & .84 \\
\hline $\begin{array}{l}\text { 5. I can discover for myself certain principles or rules prior to completing } \\
\text { the assignment }\end{array}$ & 4.08 & .83 \\
\hline $\begin{array}{l}\text { 6. I can determine how to go about as I attempt to complete the assigned } \\
\text { activities }\end{array}$ & 4.18 & .69 \\
\hline $\begin{array}{l}\text { 7. The activities assigned in the class are relevant to what I'll be using in the } \\
\text { future }\end{array}$ & 4.50 & .75 \\
\hline I am aware of the purpose of the activities given by the lecturer & 4.34 & .87 \\
\hline
\end{tabular}

The difference between male and female students' intrinsic motivation using digital learning platforms in learning English

Table 4 shows the descriptive statistics between gender concerning their intrinsic motivation using digital learning platforms in learning English. The preliminary analysis demonstrates that male students $(\mathrm{M}=4.26, \mathrm{SD}=.55)$ had a higher mean score than female students $(\mathrm{M}=4.06, \mathrm{SD}=.75)$.

Table 4. Descriptive statistics of gender differences of students in intrinsic motivation using digital learning platforms in learning English

\begin{tabular}{lllccc}
\hline & Gender & $\mathrm{N}$ & Mean & Std. Deviation & Std. Error Mean \\
\hline Intrinsic & Male & 45 & 4.26 & .55 & .08 \\
Motivation & Female & 27 & 4.06 & .75 & .14 \\
\hline
\end{tabular}


Further analysis using an independent t-test was conducted to identify any differences concerning students' intrinsic motivation when they were assigned to use various digital learning platforms in learning English. Table 5 shows that there was no significant difference in the scores for male $(\mathrm{M}=4.26, \mathrm{SD}=.55)$ and female students $(\mathrm{M}=4.06, \mathrm{SD}=.75) \mathrm{t}(70)=1.40, \mathrm{p}=$ .16 , two-tailed). These results suggest that students' intrinsic motivation of using digital learning platforms in learning English was not affected by their gender. Specifically, the findings demonstrate that using various digital learning platforms does not contribute to males' and females' intrinsic motivations in language class.

Table 5. Independent sample t-test of gender differences of students in intrinsic motivation using digital learning platforms in learning English

\begin{tabular}{|c|c|c|c|c|c|c|c|c|c|c|}
\hline & & \multicolumn{2}{|c|}{$\begin{array}{l}\text { Levene's } \\
\text { Test for } \\
\text { Equality of } \\
\text { Variances }\end{array}$} & \multicolumn{7}{|c|}{ T-test for Equality of Means } \\
\hline & & \multirow[t]{2}{*}{$\mathrm{F}$} & \multirow[t]{2}{*}{ Sig. } & \multirow[t]{2}{*}{$\mathrm{t}$} & \multirow[t]{2}{*}{ df } & \multirow[t]{2}{*}{$\begin{array}{l}\text { Sig. } \\
(2- \\
\text { tailed) }\end{array}$} & \multirow[t]{2}{*}{$\begin{array}{c}\text { Mean } \\
\text { Difference }\end{array}$} & \multirow[t]{2}{*}{$\begin{array}{l}\text { Std. Error } \\
\text { Difference }\end{array}$} & \multicolumn{2}{|c|}{$\begin{array}{l}\text { 95\% Confidence } \\
\text { Interval of the } \\
\text { Difference }\end{array}$} \\
\hline & & & & & & & & & Lower & Upper \\
\hline & $\begin{array}{l}\text { Equal } \\
\text { variances }\end{array}$ & 3.70 & .058 & 1.40 & 70 & .16 & .21 & .15 & -.09 & .52 \\
\hline $\begin{array}{l}\text { Mean Intrinsic } \\
\text { Motivation }\end{array}$ & $\begin{array}{l}\text { assumed } \\
\text { Equal } \\
\text { variances } \\
\text { not assumed }\end{array}$ & & & 1.29 & 42.70 & .20 & .21 & .16 & -.11 & .55 \\
\hline
\end{tabular}

\section{The difference in intrinsic motivation with students' achievement in English using digital} learning platforms

A one-way between-groups analysis of variance was conducted to explore the differences in intrinsic motivation with students' achievement in English using digital learning platforms. Students in the study were divided into four groups according to English grades (Group 1: Outstanding Achievement; Group 2: Above Achievement; Group 3: Average Achievement; 4: Below Average Achievement). Table 6 and Table 7 show no statistically significant difference at the $\mathrm{p}<.05$ level in intrinsic motivation scores' of using digital learning platforms for the four groups: $F(2,69)=.51, p=.01$. Moreover, in Table 7 , the Sig. value ( $\mathrm{p}$-value) is larger than .05, showing no significant difference among the four groups' mean scores of intrinsic motivations.

Table 6. Test of Homogeneity of Variances

Mean Intrinsic Motivation

Levene Statistic

df1

df2

Sig.

Table 7. Anova

$\begin{array}{lccccr} & \text { Sum of Squares } & \text { df } & \text { Mean Square } & \text { F } & \text { Sig. } \\ \text { Between Groups } & 1.07 & 2 & .53 & 1.34 & .27 \\ \text { Within Groups } & 27.37 & 69 & .39 & & \\ \text { Total } & 28.43 & 71 & & \end{array}$


Arab World English Journal (AWEJ) 2nd Special Issue on Covid 19 Challenges January 2022

Investigating the Intrinsic Motivation among Second Language Learners

Ali

\section{Perceived enjoyable digital learning platforms among the students}

The researcher employed five digital learning platforms to administer class activities: Canva, Mind map tool, Google Drawing, Google Docs, and LinkedIn. Respondents were required to choose one digital learning platform they found most enjoyable. Table 5 shows the number of students who preferred each digital learning platform used in the synchronous or asynchronous class. It indicates that Canva obtained the highest preferred digital learning platform by 38 students. The second is LinkedIn (21 students), the fourth is the mind map tools (12 students), the third is the Google Drawing (9 students), and finally Google Docs (2 students).

Table 8. Types of digital learning platforms preferred by the students

\begin{tabular}{lc}
\hline Types of the digital learning platform & Total number of students \\
\hline Canva & 38 \\
Mind map tool & 12 \\
Google Drawing & 9 \\
Google Docs & 2 \\
LinkedIn & 21 \\
\hline Total number of students & 72 \\
\hline
\end{tabular}

Further analysis was conducted to analyze the responses made by the students concerning their preferred digital learning platforms. In preparing the activities for the classes, it was observed that intrinsic motivation could be developed among them when the teacher designed the classroom using various techniques. These include using infographics, writing platforms, and online drawing tools. It was identified that the majority of the students liked to use Canva for the assigned activities. Below are some of the excerpts from students stating their motivation using Canva to complete the activities given by the teacher.

S1 : Canva because it is fun and interesting to use

S12 : ... because you can express your meaning more clearly with pictures.

S13 : Using Canva to create poster, because it easy to use and have many template that we can choose.

S22 : One activity that interesting to me was when we were asked to used Canva to create a poster. Canva has a lot of interesting features in it. Aside from poster creation, Canva also can be used to create flyer, video, logo and others. The website also prepared template for the user to use or get the idea from the template.

S35 : Creating post on Canva. Because I able to improve my creativity on creating notes that given

S51 : The reason why I like the activities using canva because I can anything related to the infographic been tasked

S55 : I like the first activity and the activity in the 3rd week given by the lecturer, which is to make a poster to introduce yourself and an infographic based on the questions that have been set. Both of these activities are using Canva.

S56 : Creating infographics using Canva software. It is interesting because I can use my own creativity to create the infographic 
From the responses, it could be understood that the use of Canva motivated the students to learn English since the platform was fun and exciting. Also, it enabled them to use available templates, promoted their creativity as they responded to the activity, and employed the different features offered by the platform. In the use of LinkedIn, students were motivated to use the networking site due to these reasons:

S5 : Post activity in LinkedIn, because $i$ can share the activity with the others.

S10 : The posts that we made on Linked In. Surprisingly it garnered attention from other LinkedIn members and gave me new insight on bio mimicry, which I had no idea about until I was assigned the task

S17 : LinkedIn. Because it give more exposure to the company for my profile.

S29 : The most interisting activities so far is relate the nature and engineering by using the Linked

S38 : I interest with the activity that used LinkedIn because $i$ manage to gain some knowledges as i do read what are the other classmates being post on LinkedIn about the certain activities given besides $i$ can improve my reading skills also my grammar and vocabulary used.

S44 : The activity that really attract me is when I need to post something on LinkedIn. It is because its make me feel fun to express my story using English.

S67 : The posts that my lecturer asked us to post on LinkedIn, $i$ find it so interesting because it helps to bring out my inner self as $i$ write on the post.

From the responses, students were motivated to use LinkedIn because they were happy as their networks read and responded to their postings. S10, for instance, felt joyful when a friend provided his insights regarding biomimicry when he posted something on engineering and nature. S38 was motivated to use LinkedIn since he could improve her grammar and vocabulary. Many of them found posting a particular topic interesting since they could share their thoughts with others (S5 and S44). At the same time, S67 was enthusiastic about using LinkedIn since he could express his inner self.

Interestingly, using mind maps via the Internet is a new experience for S63. She was not aware that there was a website to draw a mindmap. She said, "I actually wasn't aware that there are online template for mind map until we had to perform the activity". While for S9, he was motivated to use a mind map because he could make short notes. Likewise, S48 was inspired to use mindmap because it was easy to read the quick notes using appropriate keywords. S46 was motivated to use it since he worked on his iPad. He said, "Drawing mind map is interesting for me because I can utilise my iPad. Apps that I use for mind map is MindNote". Likewise, S64 commented about the software that motivated her to use a mindmap to learn English. She said, "Drawing mind maps. It brings out the creativity in me sometimes by using Draw.Io". Moving on now to consider the students' motivation using Google Drawing, S37 remarked, "... Google drawing, it was my first time using it and I just know that everyone can use the shared link just like Google Docs". Finally, the least preferred digital platform is Google Docs. S19 opined that the free platform made him motivated to use Google Docs. He said, "Google docs because it is a 
Arab World English Journal (AWEJ) 2nd Special Issue on Covid 19 Challenges January 2022

Investigating the Intrinsic Motivation among Second Language Learners

Ali

free tool". Meanwhile, S43 noted that she was motivated to use Google Docs because it is a simple tool. She said, "Google Docs is simple to use".

\section{Discussion}

In discussing students' intrinsic motivation using digital learning platforms in learning English, Alakrash et al. (2021) contended that students' motivation might be heightened due to technology integration in learning activities. Moreover, according to the researcher, with good strategic plans, technology-supported materials could motivate students to engage in classroom activities. Their study found that learning EFL improved their listening, speaking, and writing skills. The study results confirmed that intrinsic motivation could be demonstrated when the students are motivated to learn English. One of the students in Ambarwati and Mandasari (2021) was motivated using Google Classroom since she set learning goals in learning English. The motivation to learn English was the highest mean found in the study. The researchers concluded that teachers need to play their roles by providing various techniques to help students be more motivated intrinsically using digital learning platforms throughout the pandemic. This finding is consistent with Idaryani and Fidyati (2021), who found that digital technology could ignite students' intrinsic motivation. Its use enabled them to promote their ideal self and be successful in their future undertaking. The researchers also suggested that virtual reality programs could expose them to globalized workplaces. Therefore, teachers could design interesting English for Specific Purposes (ESP) learning by integrating suitable digital technology to develop students' ideal selves. Likewise, in the current study, students could be autonomous and independent when they were in power to control their learning activities. They completed the activities, not for getting marks, avoiding punishment or penalty from the teacher. Instead, they delivered the assigned tasks because they were enthusiastic about doing so.

The second question in this study sought to determine whether there are any significant differences between male and female students' intrinsic motivation using digital learning platforms in learning English. The study found no differences comparing gender in the use of digital learning platforms. This finding was also reported by Chen et al. (2021), who found no significant differences in the overall learning performance, complexity, and multiple perspectives between genders in using Moodle and Topic Analysis Instant Feedback System (TAIFS). Nevertheless, the use of TAIFS seemed to be important as one of the interviewees claimed that without the digital learning platform, he/she lose motivation to read his/her friends' responses in discussing matters related to their learning. The researchers concluded that the implicit guidelines in using TAIFS and Moodle motivated students' willingness to learn and promoted personal self-determination to participate in class. However, motivation with gender differences may not be achieved if they are unfamiliar with a particular technology and require more time to use it. Such was demonstrated in Ali and Muhammad's (2019) study as they were no difference in male and female students' use of technology to learn vocabulary. Playing the vocabulary apps for once within a short time could not develop motivation among the L2 learners. However, the current study's finding is contrary to Bujang et al.'s (2020) study. Their study found that female students were more interested in using Curriculum Information Document Online System (CIDOS) than their counterparts. Female learners enjoyed using the online learning platform used among the polytechnic lecturers and students because they could access teaching materials such as notes, assignments, and videos. They could also perform quizzes and tests via the digital learning platform. In their study, male students were more interested in using mobile apps such 
Arab World English Journal (AWEJ) 2nd Special Issue on Covid 19 Challenges January 2022

Investigating the Intrinsic Motivation among Second Language Learners

Ali

as Kahoot! and Quizizz in their learning. Another interesting finding of their research was that both genders had an equal interest in using YouTube for their digital learning experiences.

The results from the study revealed that there were no significant differences for male and female students in relation to their perceived usefulness and attitudes while playing VocBlast. These results may be explained by the fact that VocBlast is still new to the students, and thus more time is required to play the game.

For the third research question, it was found that there were no significant differences in students' intrinsic motivation with their achievement in English using digital learning platforms. In other words, their motivation to learn using digital learning platforms did not contribute to their achievement in English. There are, however, possible explanations for the findings. First, their achievement was based on their previous semester's grades. It would be more accurate to identify their motivation in terms of the relationship between their immediate scores and the assigned learning activities after they have used the digital learning platforms. Second, the four categories of achievements showed that all students were exceptional to satisfactory grades. The results might be different if they were passing and failed students as samples in the current study to compare their intrinsic motivation with their achievement in English using the digital learning platforms. Although the study found that students could be autonomous in their learning, it could not find evident concerning to what extent the students could be in control of their learning when motivation was associated with grades. Klein (2020) argued that in this pandemic situation, it seems that grades have lost their sense of meaning. Schools nowadays have removed grades entirely, or they were frozen in time. Grades were eliminated to ensure students could do well in schools. The author added that the strategies of rewarding grades to students if they scored an A in the five-paragraph essay seem not to be working during the pandemic. Instead, teachers should tap into intrinsic motivation among their students. Teachers, therefore, need to shift from teaching their students to facilitating the latter's learning.

It was estimated that participants perceived the enjoyment of using digital learning platforms differently. Findings obtained from the fourth research question identified that Canva was the most preferred digital learning platform. This finding was also reported by Utami and Djamdjuri (2021). Their study found that the use of Canva increased students' motivation levels in writing class. The researchers argued that the motivation promoted among the students enabled them to be successful in their writing.

In contrast to the current study and Utami and Djamdjuri's (2021) findings, Christiana and Anwar's (2021) samples were not motivated to use Canva. Samples who were English teachers in their study were reported not being motivated to use the platform in their teaching. More than half of the teachers were not interested in using it but would prefer to use other virtual digital media such as PowerPoints. They responded that Canva did not significantly improve their students' learning. The present study also found that students preferred using Google Docs the least compared to other digital learning platforms. This discrepancy could be attributed to not getting feedback from the teacher after students submitted their works. Referring to Table 3, concerning students' intrinsic motivation profile, the statements related to getting sufficient feedback obtained the least mean scores. Such was contrary to Srur's (2019) study since the teachers provided formative feedback to the Swedish students learning English. Teachers in their 
study took the effort commenting on their students' works, although it consumed a lot of their time. The findings of Sa'diyah and Nabhan (2021) also contradicted the results in the current study as far as Google Docs was concerned. Students in their study were enthusiastic about using the platform to improve their writing tasks collaboratively. The platform employed during the pandemic made them enjoy digital learning experiences. Also, its uses enhanced their abilities in using technology during writing classes.

\title{
Conclusion
}

The present research aimed to examine the intrinsic motivation among L2 learners when digital platforms were used during the Covid-19 pandemic. This study has shown that students were motivated to complete the class activities using various digital learning platforms, for instance, Canva, LinkedIn, mind map tools, Google Classroom and Google Docs. Yet, there was no significant difference in the genders' motivation or grades in using the medium. The evidence from this study suggests that students' preferences of using the digital platform depended on the types of activities employed in the class during the pandemic. It also implied that there is no one right way of utilizing the tools for learning English. Canva, Google Docs, LinkedIn are among the platforms that could assist students in facilitating their writing. The insights gained from this study may help English teachers planning to identify the possible digital learning platforms for their classes.

Nevertheless, as has been stated, all the digital learning platforms in the current study were used to enhance their writing skills. Therefore, future studies need to be carried out employing other digital learning platforms to improve and enhance other skills in English, i.e., reading, speaking, and listening. Although the current study gathered its data using close-ended and open-ended questionnaire items only, the findings suggest that it was essential to identify the learning platforms that make students enthusiastic about learning English. It is crucial to determine students' motivation since interest, enjoyment, and satisfaction drive them to sustain their learning rather than rewarding them.

\begin{abstract}
About the Author:
Associate Prof. Dr. Zuraina Ali is a Senior English lecturer at the Centre for Modern Languages in Universiti Malaysia Pahang (UMP). She has co-authored several English textbooks that are used in the university. She has also contributed to writing academic papers on vocabulary learning and uses of technology in Second Language Learning at tertiary level. Her research interests include Technology-related issues on language teaching, ESL/EFL education especially with beginners in an e-Learning environment, the use of new web-based learning environments to support learning and vocabulary learning among language learners. ORCID ID: https://orcid.org/0000-0002-1527-6320
\end{abstract}

\section{References}

Ali Z., \& Muhammad N.N. (2019). Gender Differences in Perceived Usefulness and Attitudes Towards VocBlast in Learning Specialized Vocabulary. In A. B. M. (eds) Mohamad Noor M., Ahmad B., Ismail M., Hashim H. (Ed.), Proceedings of the Regional Conference on Science, Technology and Social Sciences (RCSTSS 2016). Springer, Singapore. https://doi.org/https://doi.org/10.1007/978-981-13-0203-9_22 
Arab World English Journal (AWEJ) 2nd Special Issue on Covid 19 Challenges January 2022

Investigating the Intrinsic Motivation among Second Language Learners

Ali

Ambarwati, R., \& Mandasari, B. (2021). Students'motivation Toward The Use Of Google Classroom In Learning English During Covid-19 Pandemic At SMA N 1 Sukoharjo. Journal of Arts and Education, 1(1).

Brown, H. D. (2000). Principles of language learning and teaching (Vol. 4). Longman New York.

Brown, S. (2021, February 12). Digital education platforms and how they're helping schools DfE Digital and Technology. https://dfedigital.blog.gov.uk/2021/02/12/digital-educationplatforms/

Bujang, S. D. A., Selamat, A., Krejcar, O., Maresova, P., \& Nguyen, N. T. (2020). Digital Learning Demand for Future Education 4.0 — Case Studies at Malaysia Education Institutions. Informatics, 7(2), 13.

Chen, C.-M., Li, M.-C., Chang, W.-C., \& Chen, X.-X. (2021). Developing a Topic Analysis Instant Feedback System to facilitate asynchronous online discussion effectiveness. Computers \& Education, 163, 104095.

Coote, D., \& Dunleavy, B. (n.d.). Fears of pandemic stoked as more countries confirm COVID19 cases. Retrieved November 27, 2021, from https://www.upi.com/Top_News/WorldNews/2020/02/27/Fears-of-pandemic-stoked-as-more-countries-confirm-COVID-19cases/2271582796150/

Creswell, J. W. (2014). The Selection of a Research Approach. In Research Design:Qualitative, Quantitative, and Mix Methods Approaches (4th ed., pp. 3-23). SAGE. https://doi.org/45593:01

Fansury, A. H., Januarty, R., \& Ali Wira Rahman, S. (2020). Digital content for millennial generations: Teaching the English foreign language learner on COVID-19 pandemic. Journal of Southwest Jiaotong University, 55(3).

Haratikka, H. (2020). Learning English Activity in STIE Bina Karya During the Pandemic. International Conference on the Teaching English and Literature, 1(1), 110-117.

Harman, M. (2021, March 8). The Role of Digital Learning Platforms in the Academic Growth of Students - Kitaboo. https://kitaboo.com/the-role-of-digital-learning-platforms-in-theacademic-growth-of-students/

Kaharuddin, A. (2020). Contributions of Technology, Culture, and Attitude to English Learning Motivation during COVID-19 Outbreaks. Systematic Reviews in Pharmacy, 11(11), 76-84.

Klein, T. (2020). Grades Fail at Motivating Students. Intrinsic Motivation Works Better. | EdSurge News. https://www.edsurge.com/news/2020-05-21-grades-fail-at-motivatingstudents-intrinsic-motivation-works-better

Li, C., \& Lalani, F. (2020). The rise of online learning during the COVID-19 pandemic|World Economic Forum. https://www.weforum.org/agenda/2020/04/coronavirus-education-globalcovid19-online-digital-learning/

Masterson, M. (2020). An exploration of the potential role of digital technologies for promoting learning in foreign language classrooms: Lessons for a pandemic. International Journal of Emerging Technologies in Learning (IJET), 15(14), 83-96.

Nartiningrum, N., \& Nugroho, A. (2020). Online learning amidst global pandemic: EFL students' challenges, suggestions, and needed materials. ENGLISH FRANCA: Academic Journal of English Language and Education, 4(2), 115-140.

Nugroho, A., \& Atmojo, A. E. P. (2020). Digital Learning Of English Beyond Classroom: Efl Learners'perception And Teaching Activities. JEELS (Journal of English Education and Linguistics Studies), 7(2), 219-243. 
Arab World English Journal (AWEJ) 2nd Special Issue on Covid 19 Challenges January 2022

Pallant, J. (2005). SPSS Survival Guide: A Step by Step Guide to Data Analysis Using SPSS for Windows (3rd Editio). University Press.

Regoniel, P. (2015). Conceptual Framework: A Step by Step Guide on How to Make One. https://simplyeducate.me/2015/01/05/conceptual-framework-guide/

Ryan, R. M., \& Deci, E. L. (2000). Intrinsic and Extrinsic Motivations: Classic Definitions and New Directions. Contemporary Educational Psychology, 25, 54-67. https://doi.org/10.1006/ceps.1999.1020

Sa'diyah, H., \& Nabhan, S. (2021). Collaborative Writing Using Google Docs in an EFL Classroom: Voices from High School Students. VELES Voices of English Language Education Society, 5(2), 156-166.

Srur, L. (2019). A study regarding upper secondary teachers' beliefs on the use of Google docs in the English classroom. Malmö universitet/Lärande och samhälle. https://www.divaportal.org/smash/get/diva2:1492260/FULLTEXT01.pdf

Subakthiasih, P., \& Putri, I. G. A. V. W. (2020). An Analysis of Students' Motivation in Studying English During Covid-19 Pandemic. Linguistic, English Education and Art (LEEA) Journal, 4(1), 126-141.

Towne, L., \& Shavelson, R. J. (2002). Scientific research in education. National Academy Press Publications Sales Office.

Utami, Y., \& Djamdjuri, D. S. (2021). Students'motivation In Writing Class Using Of Canva: Students'perception. English Journal, 15(2), 83-92. 